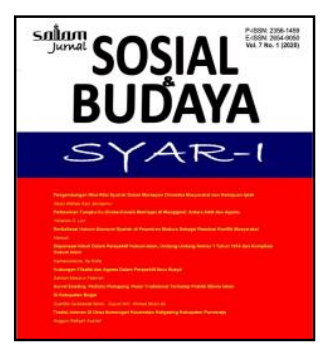

P-ISSN: 2356-1459. E-ISSN: 2654-9050

Vol. 8 No. 2 (2021), pp. 383-404

DOI: 10.15408/sjsbs.v8i2.19987

http://journal.uinjkt.ac.id/index.php/salam/index

\title{
The Effect of Intangible Asset On Competitive Advantage and Firm Performance; Study on Budget Accommodation in Semarang City
}

\author{
Armania Putri Wardhani, Amie Kusumawardhani, Muhammad Ubaidillah \\ Universitas Diponegoro, Semarang \\ Email: armaniawardhani@lecturer.undip.ac.id
}

\begin{abstract}
$10.15408 /$ sjsbs.v8i2.19987
\section{Abstract}

This research examines the effect of innovative capability, knowledge management and intellectual capital (intangible assets) on competitive advantage and firm performance (studies on budget accommodation in Semarang). The increasing number of hotels in Semarang city is an intriguing phenomenon; considering the background of the city itself for its lack of fame on its tourism business. However, it does not hinder investors' intention to keep opening their businesses in the area of accommodation services. The results of the pre-research interview stated that the increasing competition made the occupancy level troubling for the accommodating service entrepreneurs, both budget accommodation and standard and upper-class hotels. This research processed 50 samples consisting of 1 - 3 star hotels, budget hotels (non-star ones) and guesthouses. The data collection method was collected by spreading out questionnaire form to the respondents. Furthermore, the data was processed using analysis tool known as Partial Least Square (PLS). This study concludes that innovative capability, knowledge management, and intellectual capital which are part of the intangible assets of the firm have a positive effect on competitive advantage. Furthermore, competitive advantage also has a positive influence on firm performance. This study provides managerial implications that budget accommodation service entrepreneurs are able to improve their competitive advantage and firm performance through understanding and managing their intangible assets.
\end{abstract}

Keywords: firm performance, competitive advantage, innovative capability, knowledge management, intellectual capital.

\begin{abstract}
Abstrak:
Penelitian ini menguji pengaruh kapabilitas inovatif, manajemen pengetahuan dan modal intelektual (aset tidak berwujud) terhadap keunggulan kompetitif dan kinerja perusahaan (studi tentang akomodasi anggaran di Semarang). Meningkatnya jumlah hotel di kota Semarang merupakan fenomena yang menggelitik; mengingat latar belakang kota itu sendiri karena kurangnya ketenaran pada bisnis pariwisatanya. Namun hal tersebut tidak menghalangi niat investor untuk tetap membuka usahanya di bidang jasa akomodasi. Hasil wawancara pra penelitian menyatakan bahwa persaingan yang semakin ketat membuat tingkat hunian semakin meresahkan pengusaha jasa akomodatif, baik akomodasi budget maupun hotel standar dan kelas atas. Penelitian ini mengolah 50 sampel yang terdiri dari hotel bintang 1 3, hotel melati (non bintang) dan losmen. Metode pengumpulan data dilakukan dengan menyebarkan kuesioner kepada responden. Selanjutnya data diolah dengan menggunakan alat analisis yang dikenal dengan Partial Least Square (PLS). Penelitian ini menyimpulkan bahwa kapabilitas inovatif, manajemen pengetahuan, dan modal intelektual yang merupakan bagian dari aset tak berwujud perusahaan berpengaruh positif terhadap keunggulan bersaing. Keunggulan bersaing juga berpengaruh positif terhadap kinerja perusahaan. Studi ini memberikan implikasi manajerial bahwa pengusaha jasa akomodasi anggaran mampu meningkatkan keunggulan kompetitif dan kinerja perusahaan melalui pemahaman dan pengelolaan aset tidak berwujud mereka.
\end{abstract}

Kata Kunci: Kinerja perusahaan; Keunggulan bersaing; Kapabilitas inovatif; Manajemen pengetahuan; Modal intelektual 


\section{A. INTRODUCTION}

Tourism and business industry are growing rapidly in Central Java, Indonesia. In recent years, new hotels have sprung up throughout the aforementioned area. Not only are the budget hotels growing expeditiously, but hotels with medium to upper facilities are also present to enliven the hotel competition in Central Java. As in the city of Semarang, it has been supported by the existence of stacking buses to tour the city, making investors feel inclined to join in the increasingly crowded hotel competition.

Based on BPS data in 2016 (Figure 1.1), the development number of hospitality accommodation business has been growing speedily. The birth of new hotels in Semarang did not dampen the enthusiasm of investors to join this competition. Recently, the luxury Tentrem hotel owned by the Sido Muncul Group will be opened not far from heart of Semarang city, namely Simpang Lima, on 123, Gajah Mada Road, Semarang. Irwan Hidayat, the managing director of Sido Muncul group has appeared in an interview with kompas.com and stated, "Semarang is the best place to live. In 2019, I believe a lot of expatriates live in this city. Therefore, facilities such as this one will be in high demand" (Nurdin, 2016). Deputy Chairperson of Central Java PHRI, Benk Mintosih also mentioned that the average occupancy rate in Semarang City is still not high enough. "The average occupancy rate is only around $60 \%$. It can reach $70 \%$ even during Eid Mubarak event last time," Benk said when met by Semarangpos.com at the Star Hotel, some time ago. He also further stated, "Now what needs to be immediately considered is how to fill them [hotel rooms]. Creative strategies are needed from hotel industry players to attract visitors" (Yuda, 2017).

Seeing this phenomenon, investors do not hesitate to follow the competition of the accommodation services business. Although according to the PHRI vice chairman, the existence of a budget hotel needs to be stopped as they grows too rapidly. The reason to stop these budgeting services is to prevent a "price war", resulting in unfair competition (Solopos, 2017). This is the reason why economical budget hotels or commonly called budget hotels are put on spotlight.

The importance of seeing the firm's performance in business sustainability and meeting its needs have required the firm to be able to develop its competitive advantage. The development of intangible assets is one of the efforts to create competitive advantage. The firm's capability to understand what it has to support its business and what needs to be addressed are the main points on how to adapt in this intense competition.

The problem lies in the spotlight of this study is how accommodation budget is able to achieve the firm performance targets in the midst of increasingly fierce competition. This research tried to offer alternative solutions from the firm's internal perspective, namely by examining the intangible assets of the firm.

As proven by Todericiu and Saint's research (2015), managing intangible assets is a strategic activity that has a large influence on the performance of the firm. In addition, previous research has also been conducted by Rudež and Mihalic in their 2007 study which said that a very large manager's role is needed not only in managing 
the intangible assets of the firm but also developing those assets where the intangible assets significantly influence financial performance.

From the research problems that have been described which are derived from previous research, and also scrutinizing from the business phenomena that exist in the budget accommodation, this study tried to provide answers to the questions below: Does the Innovative Capability affect Competitive Advantage? Does Knowledge Management affect Competitive Advantage? Does Intellectual Capital affect Competitive Advantage? How does Competitive Advantage Affect Firm Performance?

\section{B. LITERATURE REVIEW}

\section{Firm Performance}

Firm performance is the result of the overall activities of the firm's management in achieving its goals. The increasingly fierce condition of business competition makes firm cares about the strategies carried out for their own survival (Snowden, 2016). The firm's ability to adapt is the key to maintaining its business. The importance of knowing the firm's performance is to assess the strategies that have been implemented while seeing how the firm will be running in the future (Lang, Angela and Watts, 2014).

The ability to achieve firm goals efficiently is an achievement of firm performance (Daft, 2000). Firm performance is a measure of performance that may not only depend on the efficiency of the firm itself but also on the market where it operates (Munir, 2015). In addition, firm performance is not only seen from its financial performance, but also more thoroughly in order to meet the needs of stakeholders and organizations for it to survive (Al-alak \& Tarabieh, 2011).

Various ways can be done to assess firm performance, among others are viewed from the perspective of financial performance, its products and markets which can be measured through profitability, return investment, product reliability, number of products with unique characteristics, market share and customer satisfaction (Kalkan , Bozkurt, and Arman, 2014).

In this research, firm performance, using the accommodation service provider performance indicators, can be seen from the values of the statistics produced, such as the value of Hotel Occupancy Rate (TPK), value of Bed Used in Hotel Rate (TPTT), Average Length of Stay (RLM), hotel guests (which are distinguished from foreign and domestic guests) and Hotel Double Use Rate (TPGK) (Central Statistics Agency, 2017).

\section{Competitive Advantage}

Hitt, Ireland, and Hoskisson, (2009) argue that companies have a competitive advantage when they can implement strategies that cannot be duplicated by competitors or if the strategy is too expensive to replicate. An organization can be confident that its strategy has produced one or more competitive advantages that are 
fruitful only after the competitor attempts an effort to duplicate its strategy has stopped or failed. In addition, companies must understand that there is no permanent competitive advantage. The intended speed is when a firm's commissioner is able to acquire the skills needed to duplicate the benefits of a firm's value creation strategy to determine how long a competitive advantage will last.

Competitive advantage is the firm's capability to create positions that can be maintained in accordance with its competitors (Porter, 1998). Porter considers that the ability to produce a product at a lower cost than a competitor is one way to achieve competitive advantage (Porter, 1998). The capability referred to above is the capability that allows an organization to distinguish itself from its competitors and is a result from managerial decisions ( $\mathrm{Li}$ and Rao, 2006). Generally, this capability comes from large-scale companies that are developing and have had prior experience. In addition, the amount of production with all large amounts also reduces operational costs. Other studies suggested that competitive advantage related to the value seen by customers who see certain characteristics in the offer (differentiation) or those who feel that all their needs are met in the best way by the competitor's offer (Henderson, 2011). Miller (1987) distinguishes between two types of differentiation excellence: Innovation differentiation and market differentiation. The firm can distinguish itself in various ways, such as offering innovative characteristics, launching effective promotions, providing the best services, developing strong brand names, and so on.

$\mathrm{Wu}$ and Chen (2012) stated that competitive advantage of hotels refers to hotels that have superiority or better performance than their competitors which can be measured by four items used, namely: hotels of the highest quality, the products offered are different from other hotels, hotels that can offer uniqueness compared to their competitors, and hotels that can produce products that are superior to other competitors. The research of Tavitiyaman, Qu, and Zhang, (2011) assumed that significantly superior human resources are able to create competitive strategies in the hotel industries in the United States.

Other studies suggested competitive advantage usually produces high returns. However, this advantage attracts competition, and competition limits the duration of competitive advantage in many cases. Therefore, the most competitive advantage is temporary (Mahdi and Almsafir, 2014). Finally, it is stated that competitive advantage comes from the flexibility of an organization and its capacity to react successfully to adapt in a changing environment (Chatzoglou and Chatzoudes, 2017).

This study focuses on three indicators of competitive advantage. Flexibility is defined as the sincerity and the ability of the firm to carry out choices that have a combination (not to rule out the possibility of being recombined) according to the value requested by the customer. Responsiveness refers to the concept of a system's specific ability or functional unit to complete a task in a given time (Agha, Alrubaiee, and Jamhour, 2011). Other indicators called cost saving are described as cost efficiency of competitive advantage in market competition (L. Li and Zhao, 2006). 


\section{Innovative Capability}

Innovation is seen as the firm's capacity to find and create new resources and to produce products and services that are superior to those offered by competitors. This is an important key in competitive advantage and long-term success in market competition because organizations that have the capacity to innovate can face rapid environmental changes compared to static organizations. Innovation also increases efficiency in the firm itself (Costa, Micaela and Jimenez 2009). Rapid technological developments make innovation play an important role in the life of the firm (Ryeowon Leea, 2017). However, if the firm only relies on innovation in the product in maintaining its business, then market failure is more likely to occur because competitors will easily copy products or innovations made by said firm (Chiesa and Frattini, 2011). Therefore, most research has expanded its scope to include various types of innovations such as innovation in processes, organizations, and marketing to test when their relevance is effective in improving firm performance. For instance, Camisón and Villar-López (2014) reveal that organizational innovation enhances the firm's technical capabilities to develop new products and processes that lead to their best performance.

Piening and Salge (2015) show that organizational capabilities that manage various activities related to innovation could enable companies to increase the possibility of Innovative Capability process activities and profit margins. In addition, the adoption of marketing innovations has proven effective in improving firm performance (Gupta et al., 2016) and the presence of innovation supports not only competitive advantages in improving firm performance but also to maintain that competitive advantage (Chatzoglou and Chatzoudes, 2017).

Innovative Capability variable is measured using four indicators, namely product innovation, process innovation, market innovation, and service innovation. Product innovation is the ability to develop new products in the face of market needs. Process innovation means the existence of new ideas to simplify (the application of technology, tools, or techniques) the process of creating new products (Benaim, 2015). Innovation market is a condition where a firm is able to find new market segments according to the target market while service innovation refers to the firm's ability to improve the services it has (Mulyana and Sutapa, 2014).

\section{Knowledge Management}

The attention and importance of acquiring Knowledge Management in the literature and practice in previous years is downright necessary because of environmental changes such as the increasing global competition, speed of information and knowledge, product and process dynamics. The capability to innovate and the competition through the buyer's market are in line with Omotayo's research in 2015. As of the need for extensive and up-to-date knowledge, a firm is not only able to understand its internal situation, but they also understand the competition or the external conditions it faces to be more superior compared to its competitors. Therefore, 
knowledge is considered an important resource for a firm. Lai and Lin (2012) also stated that knowledge management is an optimal tool that can be applied by each firm to maintain its competitive advantage.

Based on Omotayo's research (2015), currently organizations are no longer competing solely based on capital and financial strength, but with knowledge as it is a new competitive advantage in business. In his research, Omotayo (2015) stated that knowledge is power; for that, it needs to be managed properly (knowledge management). Successful firms understand why they must manage knowledge, develop a plan for achieving this goal and devote time and energy to this effort. This is because Knowledge Management has been described as the main driver of firm performance (Bosua and Venkitachalam, 2013) and one of the most important sources for the survival and prosperity of the organization (Kamhawi, 2012). The method of collecting and organizing knowledge as an effort to increase knowledge in decision making and strategy formulation is an understanding of knowledge management as revealed by Lee and Ooi, 2016.

Knowledge management in this study was measured using three indicators including: acquisition, application and protection. Acquisition is a process that includes accessibility activities, collection and application of acquired knowledge. Application is the process of using actual knowledge. The application of knowledge allows the organization to continue to translate its organizational expertise into the product that is realized. Protection is the process of securing knowledge assets and making them safe and accessible only by authorized officers (Hassan et al, 2012).

\section{Intellectual Capital}

Intellectual Capital is defined as a summary of knowledge, skills, abilities, experience, attitudes, wisdom and creativity of employees (Bontis, 1998). The development of the concept of intellectual capital gave birth to two different but convergent directions. A direction has been generated by the need to increase the firm's competitive advantage and to gain a strategic advantage in an increasingly competitive market with intensive use of intangible resources. Of these resources, special attention is placed on information and knowledge, trademarks and patents, organizational culture and excellence-oriented behavior. In other words, this problem is related to how efficient management of intangible resources in the firm can be achieved to improve its competitiveness.

The struggle to accept intellectual capital as an important and representative concept for modern organizations in general has been successful (Andriessen, 2001). There are also studies proving that the intellectual capital of an organization is a way to create a modern and competitive environment (Petty and Guthrie, 2000). Although the importance of intellectual capital has been widely accepted in the past two decades, many organizations are still struggling with the problem of how to approach it, especially when it comes to the difficulties faced when assessing intellectual capital (Serenko and Bontis, 2013; Todericiu and Stăniț, 2015). It is also stated that intellectual 
capital is a concept related to modern economics, its value is in monitoring and identifying intangible assets that can determine the failure or success of a firm.

Managing intellectual capital is a strategic activity that affects the performance of a firm (Todericiu and Stăniţ, 2015). Competitive advantage based on intangible assets is also connected with mastery in combining resources (tangible and intangible) typically by the firm. The development of competitive advantage and efficiency is a key source for macroeconomic and microeconomic performance (Kamukama, 2013). Therefore, intellectual resources and intangible capital are important conditions for sustainable competitive advantage and for long-term development (Todericiu and Stăniţ, 2015).

As stated by (Gogan et al., 2016) intellectual capital in general includes:

(1) Human Capital - refers to the characteristics and intellectual qualities of human resources owned by companies that must react to market changes and customer needs.

(2) (2) Structural Capital - refers to an organizational component that can be described as organizational infrastructure and organizational processes used to obtain products and services.

(3) Relational Capital - refers to the ability to establish relationships with stakeholders and markets in a stable, sustainable environment; ability to build interpersonal relationships and the ability to develop relationships based on trust.

In this study, intellectual capital was seen from a managerial perspective and was measured using four indicators from two dimensions called Human Capital and Structural Capital. In this case, human capital is related to human resources in an organization which includes the education and experience of the firm's human resources. Structural capital is a system and program owned by the firm as well as research and development carried out by the firm from time to time (Kamukama, 2013). Human capital is explained by two indicators: education and experience. In this study, education indicators are described by the condition of the level of education of human resources owned by the firm while experience is seen from the background of human resources working for the firm. Structural capital is explained by two indicators, namely: systems and programs along with research and development. Systems and programs are seen by the existence of systems and programs that support firm performance, while research and development are described by the firm's ability to conduct research and development activities for the advancement of firm management (Kamukama et al., 2011).

Based on the review of literature that has been described previously, the researchers have obtained several research hypotheses as follows:

H1: Competitive advantage influences Firm Performance.

H2: Innovative Capability has a positive effect on Competitive Advantage.

H3: Knowledge Management has a positive effect on Competitive Advantage. 
H4: Intellectual Capital has a positive effect on Competitive Advantage.

\section{METHODS}

\section{Types and Data Sources}

The type of data used in this study is quantitative data. In this study, the data sources used were a primary data that was obtained through the distribution of questionnaires to hotel managers in Semarang and a secondary data obtained by researchers through books, journals, and other literatures.

\section{Research Population and Samples}

Based on his research, Roper (1989) stated that budget hotels are alternative hotels which have "limited services with reasonable prices". This study used the census method so that it took the entire population as a sample of research, namely all $1-3$ star hotels, budget hotels (non-star), guesthouses, and hostels in Semarang, adding up 106 hotels in total (Central Statistics Agency, 2017). An additional criterion for this research was when the researcher looked at the type of service provided and the price offered did not exceed three hundred fifty thousand rupiahs. Furthermore, another criterion for this research was that hotel managers who filled out questionnaires must have at least 1 year or 12 months working experience as hotel managers in accommodation services business. The unit of analysis in this study was managers who understand the strategies and objectives of the firm.

\section{Variables, Indicators and Measurements}

Table 1 below explains about 1 research variable and its indicator. The indicator questionnaire was measured using a 7-point Likert scale.

\section{Table 1}

\section{Variables and Indicators}

\begin{tabular}{ll}
\multicolumn{1}{c}{ Variables } & \multicolumn{1}{c}{ Indicators } \\
\hline $\begin{array}{l}\text { Innovative } \\
\text { Capability }\end{array}$ & $\begin{array}{l}\text { X1: Having the ability to develop new products. } \\
\text { X2: Having new ideas to facilitate the process of creating new } \\
\text { products. }\end{array}$ \\
\cline { 2 - 2 } $\begin{array}{l}\text { X3: Having the ability to find new market segments according to the } \\
\text { target market }\end{array}$ & \begin{tabular}{l} 
X4: Having the ability to improve the services that have been owned. \\
\hline
\end{tabular} \\
\hline
\end{tabular}




\begin{tabular}{|c|c|}
\hline $\begin{array}{l}\text { Knowledge } \\
\text { Management }\end{array}$ & $\begin{array}{l}\text { X5: Implement processes that include accessibility activities, } \\
\text { collection and application of acquired knowledge. }\end{array}$ \\
\hline \multirow{6}{*}{$\begin{array}{l}\text { Intellectual } \\
\text { Capital }\end{array}$} & X6: Perform the actual use of knowledge process. \\
\hline & $\begin{array}{l}\text { X7: the process of securing knowledge assets and making them safe } \\
\text { and access that can only be done by authorized officers. }\end{array}$ \\
\hline & $\begin{array}{l}\text { X8: The condition of education owned by the firm's human } \\
\text { resources. }\end{array}$ \\
\hline & X9: Experience had by the firm's human resources. \\
\hline & X10: Having a firm system and program. \\
\hline & $\begin{array}{l}\text { X11: Conducting research and development carried out by the firm } \\
\text { from time to time. }\end{array}$ \\
\hline \multirow[t]{3}{*}{$\begin{array}{l}\text { Competitive } \\
\text { advantage }\end{array}$} & $\begin{array}{l}\text { X12: The ability of a firm to carry out choices that have a } \\
\text { combination (and not the possibility of re-combining its choices) in } \\
\text { accordance with the value demanded by superior consumers. }\end{array}$ \\
\hline & $\begin{array}{l}\text { X13: The firm's ability to respond to customers' needs and desires } \\
\text { quickly. }\end{array}$ \\
\hline & X14: Having cost efficiency in producing products \\
\hline \multirow{4}{*}{$\begin{array}{l}\text { Firm } \\
\text { Performance }\end{array}$} & X15: Room Occupancy Rate \\
\hline & X16: Beds used Rate \\
\hline & X17: Average Length of Stay for hotel guests \\
\hline & X18: Dual Room Usage Rate \\
\hline
\end{tabular}

Source: obtained from primary data in 2019

\section{Data Collecting Method}

Primary data in this study were obtained by distributing questionnaires to 106 hotels in accordance to the research criteria. The distribution of research questionnaires began by making a research permit. After that, confirmation was carried out on the object of research - if the research object was willing to be examined, the process then continued until the results of the research were obtained from questionnaires distribution to the object of research.

\section{Technical Analysis}

The process of data analysis includes descriptive statistics, Structural Equation Modeling using smart PLS software which consists of several stages for testing empirical models including: Evaluation of the measurement model is done to assess the validity and reliability of the indicators forming latent variables; Structural model 
that includes the coefficient of determination and predictive relevance; The last is hypothesis testing to see the significance of the relationship between exogenous and endogenous latent variables by looking at the value of $t$-statistics and $p$-value.

\section{RESULTS AND DISCUSSIONS}

\section{Descriptive Data}

The Analysis Unit in this study was a manager who has work experience in the field of accommodation services for at least 12 months and has understood the strategy and objectives of the firm. The following is the return data from the manager of accommodation services in Semarang:

Table 2

Returned Questionnaires

\begin{tabular}{lc}
\hline \multicolumn{2}{c}{ Returned Questionnaires data } \\
\hline \multicolumn{1}{c}{ Info } & Quantity \\
\hline Previously prepared questionnaires & 106 \\
\hline Questionnaires that could be distributed & 100 \\
\hline Questionnaire that didn't return & 50 \\
\hline $\begin{array}{l}\text { Questionnaires that were returned and } \\
\text { could be processed }\end{array}$ & 50 \\
\hline
\end{tabular}

Source: obtained from primary data in 2019

\section{Evaluation of Measurement Model (Outer Model)}

\section{Validity and Reliability Tests}

The following are the output results and the loading factor values of this research model:

Figure 1

\section{PLS Initial Algorithm}




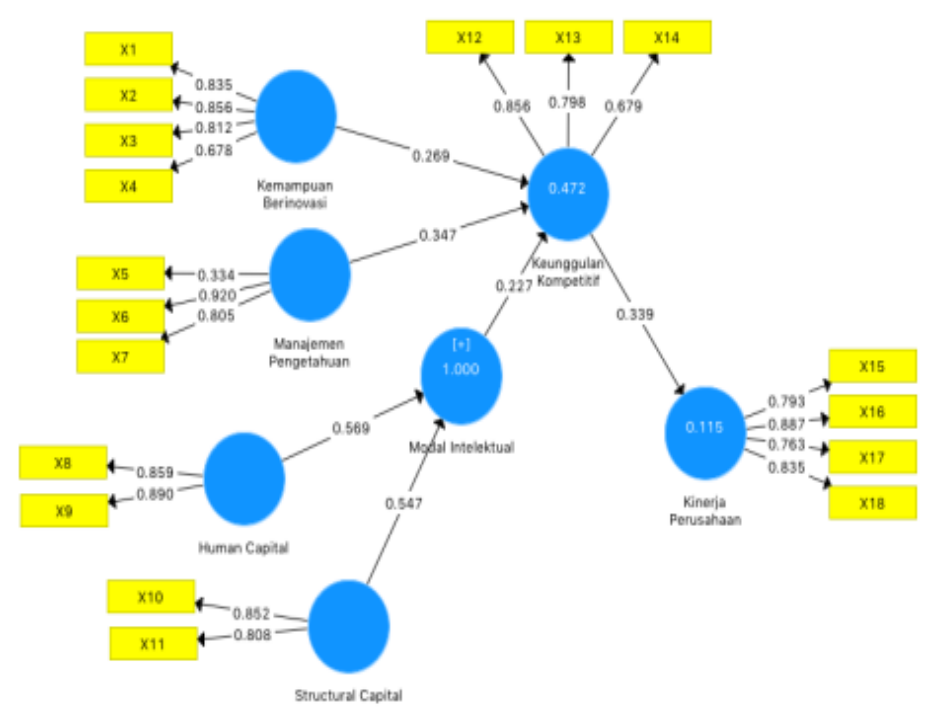

Source: obtained from primary data in 2019

Based on the picture above, the value of the loading factor in the model all fulfills the requirements, which was above 0.05 . Seeing from the next condition, which was looking at the AVE value, the model met the criteria. This is explained in table 3:

Table 3

Cronbach Alpha, Composite Reliability, and AVE values

\begin{tabular}{lccc}
\hline \multicolumn{1}{c}{ Info } & $\begin{array}{c}\text { Cronbach } \\
\text { Alpha }\end{array}$ & $\begin{array}{c}\text { Composite } \\
\text { Reliability }\end{array}$ & AVE \\
\hline Innovative Capability & 0.807 & 0.874 & 0.637 \\
\hline Knowledge Management & 0.497 & 0.667 & 0.534 \\
\hline Intellectual Capital & 0.760 & 0.848 & 0.584 \\
\hline Human Capital & 0.694 & 0.700 & 0.765 \\
\hline Structural Capital & 0.550 & 0.555 & 0.689 \\
\hline Competitive advantage & 0.679 & 0.698 & 0.610 \\
\hline Firm Performance & 0.838 & 0.839 & 0.674 \\
\hline
\end{tabular}

Source: obtained from primary data in 2019

From table 3 above, it can be seen that the Cronbach alpha value for the Knowledge Management variable is still below 0.5, which is equal to 0.497 . This value does not meet the reliability requirements. In other words, the level of knowledge management construct reliability is very weak so that to increase it, the Cronbach Alpha value is eliminated on the knowledge management indicator, which is X5. This step was done because $\mathrm{X} 5$ has the lowest loading factor value so that the model that 
has been eliminated by knowledge management using 2 indicators is still allowed in the research model. as follows:

Furthermore, the following figures are the outer models after being eliminated

\section{Figure 2}

\section{PLS Algorithm after The X5 Indicator was Eliminated}

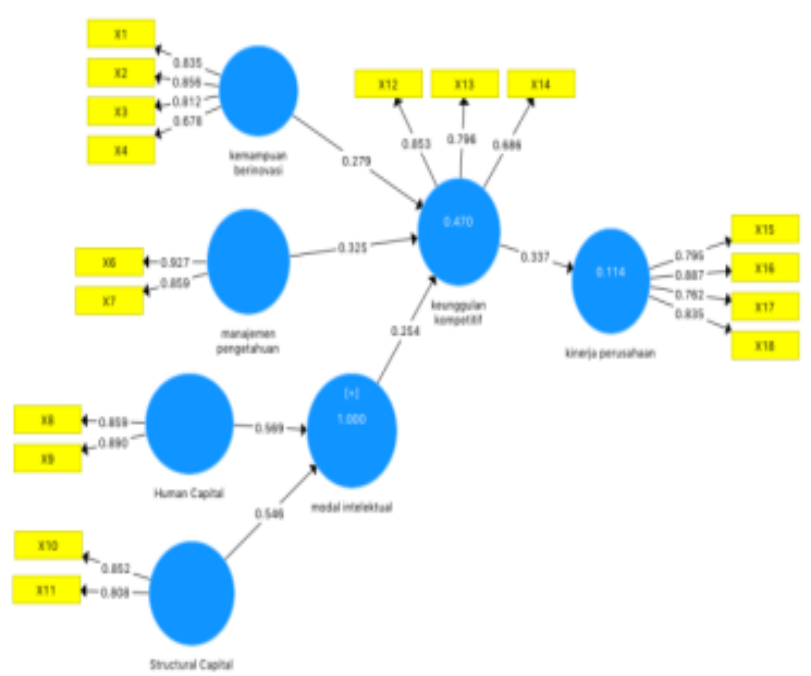

Source: obtained from primary data in 2019

Based on Figure 2, the value of the loading factor in the model has all fulfilled the requirements, which is above 0.05 . Seeing from the next condition, which was looking at the AVE value, the model has met the criteria. This result is explained in table 4.3:

Table 4

Cronbach Alpha, Composite Reliability, and AVE values

\begin{tabular}{lccc}
\hline \multicolumn{1}{c}{ Info } & $\begin{array}{c}\text { Cronbach } \\
\text { Alpha }\end{array}$ & $\begin{array}{c}\text { Composite } \\
\text { Reliability }\end{array}$ & AVE \\
\hline Innovative Capability & 0.807 & 0.874 & 0.637 \\
\hline Knowledge Management & 0.753 & 0.888 & 0.798 \\
\hline Intellectual Capital & 0.760 & 0.848 & 0.584 \\
\hline Human Capital & 0.694 & 0.867 & 0.765 \\
\hline Structural Capital & 0.550 & 0.816 & 0.689 \\
\hline Competitive advantage & 0.679 & 0.823 & 0.610 \\
\hline Firm Performance & 0.838 & 0.893 & 0.674 \\
\hline
\end{tabular}

Source: obtained from primary data in 2019 
Based on table 4, it can be concluded that the outer model has met the requirements. Furthermore, the AVE value reflects the variables and dimensions in the model. It can be said that the variance and indicators can be explained.

The next validity test was Discriminant Validity. Discriminant validity of the measurement model with reflective indicators was assessed based on cross loading measurements with constructs. If the construct correlation with the measurement item is greater than the size of the other constructs, then this result indicates that the latent construct predicts the size of their block better than the size of the other blocks (Ghozali, 2014).

Table 4.4 below shows the cross loading value for the basis of testing Discriminant Validity:

Table 5

Cronbach Alpha, Composite Reliability, and AVE Values

\begin{tabular}{llllll}
\hline & KB & KK & KP & MP & MI \\
\hline KB & $\underline{\mathbf{0 . 7 9 8}}$ & & & & \\
\hline KK & 0.534 & $\underline{\mathbf{0 . 7 8 1}}$ & & & \\
\hline KP & 0.261 & 0.337 & $\underline{\mathbf{0 . 8 2 1}}$ & & \\
\hline MP & 0.457 & 0.575 & 0.184 & $\underline{\mathbf{0 . 8 9 4}}$ & \\
\hline MI & 0.421 & 0.528 & 0.467 & 0.482 & $\underline{\mathbf{0 . 7 6 4}}$ \\
\hline
\end{tabular}

Source: obtained from primary data in 2019

Table 5 shows the cross loading value, where all indicators that make up each research variable (bold values) have met Discriminant Validity. This happened because the bold values have the biggest cross loading value for the variables it forms and not on the other variables.

Meanwhile, reliability test was done by looking at the cronbach alpha and composite reliability values in table 4.3 . It can be seen that the cronbach alpha value for Human Capital and Structural Capital is still below 0.7 but is still in the range of more than 0.5 - This is supported by the composite reliability values which are all above 0.7.

Therefore, it can be concluded that the variables and dimensions in this model have accuracy, consistency, and accuracy of instruments in measuring the constructs.

\section{Structural Model (Inner Model)}

\section{Coefficient of determination (R-Square)}

The R-Square value was used in this research to explain the influence of certain exogenous latent variables on endogenous variables to determine whether they have a substantive effect or not. However, the use of the R-Square value will cause an 
estimation bias. This is because if the variable predictor in the model increases, then the value of R-Square will be getting bigger and continually increase. Therefore, it is recommended to use adjusted $\mathrm{R}^{2}$ (Cohen, et al in Ghozali 2014). This study has an adjusted $\mathrm{R}^{2}$ value as follows:

Table 6

Cronbach Alpha, Composite Reliability, and AVE values

\begin{tabular}{cc}
\hline Variable & Adjusted $\mathbf{R}^{2}$ \\
\hline Competitive Advantage & 0.470 \\
\hline Firm Performance & 0.114
\end{tabular}

Source: obtained from primary data in 2019

In table 6 , the adjusted $\mathrm{R}^{2}$ value for competitive advantage is 0.47 . Therefore, it can be concluded that the variable variance of competitive advantage of $47 \%$ could be explained by 3 latent variables, which are: Innovative Capability, Knowledge Management, and Intellectual Capital - while the rest was influenced by other factors. Adjusted $\mathrm{R}^{2}$ value for firm performance is 0.114 ; therefore, it can be concluded that competitive advantage was able to explain the variable performance of the firm by $11.4 \%$ - while the rest is influenced by other factors beyond those that has been studied.

\section{Hypothesis testing}

The statistical test of each hypothesized relationship can be done using a simulation through the bootstrap method of the sample. This testing aims to minimize research problems on data abnormalities because bootstrap is capable of producing data that are normally distributed. Table 4.6 shows the results of the bootstrapping test from PLS analysis.

Table 7

Cronbach Alpha, Composite Reliability, and AVE Values

\begin{tabular}{llccc}
\hline \multicolumn{1}{c}{ Variable Correlation } & $\begin{array}{l}\text { Direct } \\
\text { coefficient }\end{array}$ & StdDev & $\begin{array}{c}\text { T- } \\
\text { stat }\end{array}$ & $\begin{array}{c}\text { P- } \\
\text { value }\end{array}$ \\
\hline Competitive Advantage $\rightarrow$ Firm Performance & 0.376 & 0.134 & 2.518 & 0.012 \\
\hline Innovative Capability $\rightarrow$ Competitive Advantage & 0.283 & 0.121 & 2.303 & 0.022 \\
\hline $\begin{array}{l}\text { Knowledge Management } \rightarrow \text { Competitive } \\
\text { Advantage }\end{array}$ & 0.335 & 0.130 & 2.491 & 0.013 \\
\hline Intellectual Capital $\rightarrow$ Competitive Advantage & 0.246 & 0.120 & 2.123 & 0.034 \\
\hline
\end{tabular}

Source: obtained from primary data in 2019 
In testing this hypothesis, the basis of the significance of the relationship between exogenous and endogenous latent variables was by looking at the value amount of the t-statistic and p-value. Therefore, based on table 7, hypothesis testing could be done by comparing t-statistics with t-table. T-table can be obtained from 50 respondents who in the end obtained t-table of 1.960. Table 7 provides the estimated output for testing structural models as follows:

1. The correlation of competitive advantage to firm performance has a path coefficient value of 0.376 and t-count of 2.518 greater than t-table (1.960) and significant or $\mathrm{p}$ smaller than 0.05 with $\mathrm{p}$ value of 0.012 . This result indicates that competitive advantage has a significant positive effect on firm performance. It can be concluded in $\mathrm{H} 1$ that competitive advantage influences firm performance. Therefore, $\mathrm{H} 1$ is accepted.

2. The correlation of the innovative capability to competitive advantage has a path coefficient value of 0.283 and $t$-count of 2.303 greater than $t$-table (1.960) and significant or $\mathrm{p}$ smaller than 0.05 with a $\mathrm{p}$ value of 0.022 . This result indicates that the innovative capability has a significant positive effect on competitive advantage. It can be concluded in $\mathrm{H} 2$ that innovative capability influences competitive advantage. Therefore, $\mathrm{H} 2$ is accepted.

3. The correlation of knowledge management to competitive advantage has a path coefficient value of 0.335 and $t$-count of 2.491 greater than t-table (1.960) and significant or $\mathrm{p}$ smaller than 0.05 with a $\mathrm{p}$ value of 0.013 . This result indicates that the knowledge management has a significant positive effect on competitive advantage. It can be concluded in $\mathrm{H} 3$ that knowledge management influences competitive advantage. Therefore, $\mathrm{H} 3$ is accepted.

4. The correlation of intellectual capital to competitive advantage has a path coefficient of 0.246 and $t$-count of 2.123 greater than t-table (1.960) and significant or $\mathrm{p}$ smaller than 0.05 . This result indicates that the intellectual capital has a significant positive effect on competitive advantage. It can be concluded in $\mathrm{H} 4$ that intellectual capital influences competitive advantage. Therefore, H4 is accepted.

\section{E. CONCLUSIONS}

\section{Conclusion of Research Case}

The case in this study discussed on how to improve firm performance and competitive advantage in the budget accommodation business in Semarang. Based on the results of the research in the previous chapter, there are four factors to answer the problem of this research:

1. In figure 3, the entrepreneurs of business investment services in Semarang could improve firm performance by knowing and maximizing what their competitive advantage is as the influence of competitive advantage on firm performance is positive. 
Figure 3

Competitive Advantage and Firm Performance

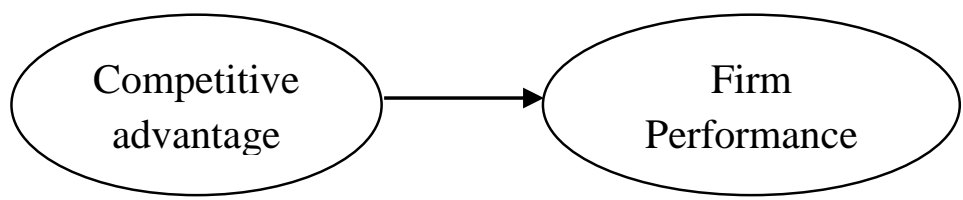

Source: obtained from primary data in 2019

In figure 3 above, the correlation of competitive advantage with firm performance has a significant positive effect. This proves that by knowing and maximizing what is a competitive advantage, entrepreneurs are able to improve its firm's performance. This result is in line with the research of Porter (1998) who claimed that Competitive Advantage is the firm's ability to create positions that can be maintained in accordance with its competitors.

2. In figure 4, business operators of budget accommodation services in Semarang are able to increase their competitive advantage by having good innovative capability because the influence of innovative capability to competitive advantage is positive.

Figure 4

\section{Innovative Capability to Competitive Advantage}

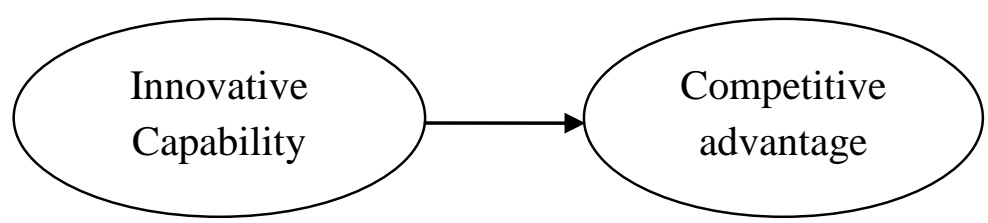

Source: obtained from primary data in 2019

In figure 4 above, the correlation between innovative capability and competitive advantage has a significant positive effect. This proves that by having good innovative capability, the firm is expected to be able to increase its competitive advantage. The firm is able to provide the best innovation to improve its quality so that it can achieve competitive advantage.

3. In Figure 5, business services budget accommodation in Semarang could increase competitive advantage by having a good knowledge management because the influence of innovative capability to competitive advantage is positive.

Figure 5

Knowledge Management to Competitive Advantage

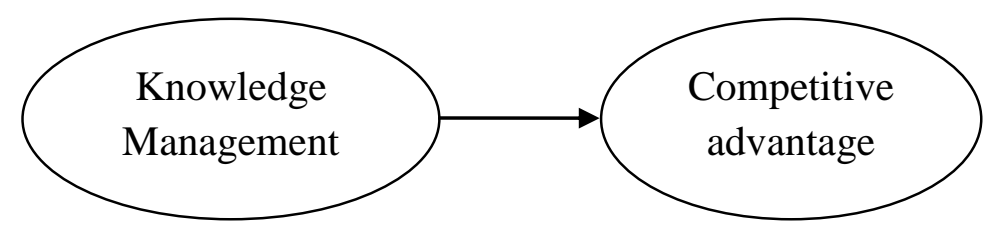




\section{Source: obtained from primary data in 2019}

In figure 5 above, the correlation between knowledge management and competitive advantage has a significant positive effect. This proves that by having good knowledge management, the firm is expected to be able to increase its competitive advantage. The firm is able to manage internal and external knowledge properly so that it can evaluate and innovate appropriately and is expected to be able to improve its quality so as to achieve competitive advantage.

4. In Figure 6, business services budget accommodation in Semarang can increase competitive advantage by having a good Intellectual Capital because the influence of Intellectual Capital to competitive advantage is positive.

\section{Figure 6}

\section{Intellectual Capital on Competitive Advantage}

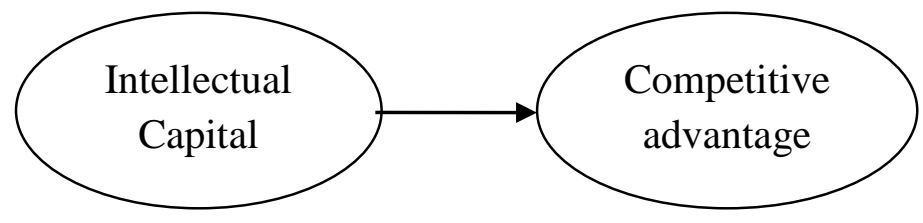

Source: obtained from primary data in 2019

In figure 6 above, the correlation between intellectual capital and competitive advantage has a significant positive effect. This proves that by having good intellectual capital, the firm is expected to be able to increase its competitive advantage. The firm is aware of the importance of intangible resources such as human capital and structural capital which are part of intellectual capital for long-term development. Therefore, firms are able to gain competitive advantage.

\section{Research Implications}

\begin{tabular}{cl}
\hline Hypothesis & \multicolumn{1}{c}{ Managerial Implications } \\
\hline $\begin{array}{c}\text { Competitive Advantage } \rightarrow \\
\text { Firm Performance }\end{array}$ & $\begin{array}{l}\text { This research proved the significant influence of } \\
\text { competitive advantage on firm performance. This result is } \\
\text { reflected in how each respondent has their own characters } \\
\text { in accordance with the "characteristics" they possess in } \\
\text { increasing the hotel's occupancy. }\end{array}$ \\
\hline $\begin{array}{l}\text { Innovative Capability } \rightarrow \\
\text { Competitive Advantage }\end{array}$ & $\begin{array}{l}\text { This study illustrated on how each innovation made by } \\
\text { the firm depends on the geographical location and the } \\
\text { market to be targeted so as to increase its competitive } \\
\text { advantage. }\end{array}$ \\
\hline
\end{tabular}


Knowledge Management

$\rightarrow$ Competitive Advantage

This research proved the importance of knowledge management. This result can be seen from several respondents who have enrolled in online budget hotel networks such as Red Doorz, mainly in managing external knowledge which also facilitates respondents and prospective customers to share their knowledge.

Intellectual Capital $\rightarrow$ Competitive Advantage
Judging from the research's output coefficient, it was evident that the indicators of human capital variables were stronger than structural capital in the dimensions of Intellectual Capital. The facts in the field also showed that respondents tend to carry out in-depth research and development because of the large amount of costs needed. However, they tend to focus more on the firm's human capital. The belief that says "right man in the right place" is a part of intellectual capital in achieving competitive advantage.

Source: obtained from primary data in 2019

\section{REFERENCES}

Agha, S., Alrubaiee, L., \& Jamhour, M. (2011). Effect of Core Competence on Competitive Advantage and Organizational Performance. International Journal of Business and Management, 7(1), 192-204. https://doi.org/10.5539/ijbm.v7n1p192

Akman, G., \& Yilmaz, C. (2008). Innovative Capability, Innovation Strategy and Market Orientation: an Empirical Analysis in Turkish Software Industry. International Journal of Innovation Management, 12(01), 69-111. https://doi.org/10.1142/S1363919608001923

Al-alak, B. A., \& Tarabieh, S. (M. Z. A. (2011). Gaining Competitive Advantage and Organizational Performance Through Customer Orientation, Innovation Differentiation and Market Differentiation. International Journal of Economics and Management Sciences, 1(5), 80-91.

Anisah, L. (2017). Sensus Ekonomi 2016 - Potensi Ekonomi Kota Semarang. Semarang. Retrieved from semarangkota.bps.go.id

Badan Pusat Statistik. (2017). Statistik Perhotelan Kota Semarang 2016. Semarang. Retrieved from https://semarangkota.bps.go.id/

Benaim, A. (2015). Measurement, Assessment and Development. Lund Unversity.

Bontis, N. (1998). Intellectual capital: an exploratory study that develops measures and models. Management Decision, 36(2), 63-76. https://doi.org/10.1108/00251749810204142

Bosua, R., \& Venkitachalam, K. (2013). Aligning strategies and processes in knowledge management: a framework. Journal of Knowledge Management, 17(3), 331-346. 
https://doi.org/10.1108/JKM-10-2012-0323

Camisón, C., \& Villar-López, A. (2014). Organizational innovation as an enabler of technological innovation capabilities and firm performance. Journal of Business Research, 67(1), 2891-2902. https://doi.org/10.1016/j.jbusres.2012.06.004

Chatzoglou, P., \& Chatzoudes, D. (2017). The role of innovation in building competitive advantages: an empirical investigation. European Journal of Innovation Management, EJIM-02-2017-0015. https://doi.org/10.1108/EJIM-

Agha, S., Alrubaiee, L., \& Jamhour, M. (2011). Effect of Core Competence on Competitive Advantage and Organizational Performance. International Journal of Business and Management, 7(1), 192-204. https://doi.org/10.5539/ijbm.v7n1p192

Akman, G., \& Yilmaz, C. (2008). Innovative Capability, Innovation Strategy and Market Orientation: an Empirical Analysis in Turkish Software Industry. International Journal of Innovation Management, 12(01), 69-111. https://doi.org/10.1142/S1363919608001923

Al-alak, B. A., \& Tarabieh, S. (M. Z. A. (2011). Gaining Competitive Advantage and Organizational Performance Through Customer Orientation, Innovation Differentiation and Market Differentiation. International Journal of Economics and Management Sciences, 1(5), 80-91.

Anisah, L. (2017). Sensus Ekonomi 2016 - Potensi Ekonomi Kota Semarang. Semarang. Retrieved from semarangkota.bps.go.id

Badan Pusat Statistik. (2017). Statistik Perhotelan Kota Semarang 2016. Semarang. Retrieved from https://semarangkota.bps.go.id/

Benaim, A. (2015). Measurement, Assessment and Development. Lund Unversity.

Bontis, N. (1998). Intellectual capital: an exploratory study that develops measures and models. Management Decision, 36(2), 63-76. https://doi.org/10.1108/00251749810204142

Bosua, R., \& Venkitachalam, K. (2013). Aligning strategies and processes in knowledge management: a framework. Journal of Knowledge Management, 17(3), 331-346. https://doi.org/10.1108/JKM-10-2012-0323

Camisón, C., \& Villar-López, A. (2014). Organizational innovation as an enabler of technological innovation capabilities and firm performance. Journal of Business Research, 67(1), 2891-2902. https://doi.org/10.1016/j.jbusres.2012.06.004

Chatzoglou, P., \& Chatzoudes, D. (2017). The role of innovation in building competitive advantages: an empirical investigation. European Journal of Innovation Management, EJIM-02-2017-0015. https://doi.org/10.1108/EJIM-022017-0015

Chiesa, V., \& Frattini, F. (2011). Commercializing technological innovation: Learning from failures in high-tech markets. Journal of Product Innovation Management, 28(4), 437-454. https://doi.org/10.1111/j.1540-5885.2011.00818.x 
Darabi, R., Kamran Rad, S., \& Ghadiri, M. (2012). The relationship between intellectual capital and earnings quality. Research Journal of Applied Sciences, Engineering and Technology, 4(20), 4192-4199. https://doi.org/10.5297/ser.1201.002

Efrat, K., Hughes, P., Nemkova, E., Souchon, A. L., \& Sy-Changco, J. (2018). Leveraging of Dynamic export capabilities for competitive advantage and performance consequences: Evidence from China. Journal of Business Research, 84(November 2016), 114-124. https://doi.org/10.1016/j.jbusres.2017.11.018

Erisman, E. (2017). Kota Semarang. Semarang. Retrieved from https://semarangkota.bps.go.id/publikasi.html

Gogan, L. M., Artene, A., Sarca, I., \& Draghici, A. (2016). The Impact of Intellectual Capital on Organizational Performance. Procedia - Social and Behavioral Sciences, 221(0), 194-202. https://doi.org/10.1016/j.sbspro.2016.05.106

Gupta, S., Malhotra, N. K., Czinkota, M., \& Foroudi, P. (2016). Marketing innovation: A consequence of competitiveness. Journal of Business Research, 69(12), 56715681. https://doi.org/10.1016/j.jbusres.2016.02.042

Henderson, S. (2011). The development of competitive advantage through sustainable event management. Worldwide Hospitality and Tourism Themes, 3(3), 245-257. https://doi.org/10.1108/17554211111142202

Jia-Sheng, L., \& Chia-Jung, H. (2010). In Relating Innovative Capability And Sustained Competitive Advantage. Journal of Business \& Economics Research, 8(9), 109119.

Kalkan, A., Bozkurt, Ö. Ç., \& Arman, M. (2014). The Impacts of Intellectual Capital, Innovation and Organizational Strategy on Firm Performance. Procedia - Social and Behavioral Sciences, 150, 700-707. https://doi.org/10.1016/j.sbspro.2014.09.025

Kamhawi, E. M. (2012). Knowledge management fishbone: a standard framework of organizational enablers. Journal of Knowledge Management, 16(5), 808-828. https://doi.org/10.1108/13673271211262826

Kamukama, N. (2013). Intellectual capital: company's invisible source of competitive advantage. Competitiveness Review, 23(3), 260-283. https://doi.org/10.1108/10595421311319834

Kamukama, N., Ahiauzu, A., \& Ntayi, J. M. (2011). Competitive advantage : mediator of intellectual capital and performance. https://doi.org/10.1108/14691931111097953

Lang, Angela; Watts, S. (2014). Capitalising on global trends.

Lee, V. H., Foo, A. T. L., Leong, L. Y., \& Ooi, K. B. (2016). Can competitive advantage be achieved through knowledge management? A case study on SMEs. Expert Systems with Applications, 65, 136-151. https://doi.org/10.1016/j.eswa.2016.08.042

Li, L., \& Zhao, X. (2006). Enhancing Competitive Edge Through Knowledge 
Management in Implementing ERP Systems, 140, 129-140.

Li, S., Ragu-Nathan, B., Ragu-Nathan, T. S., \& Subba Rao, S. (2006). The impact of supply chain management practices on competitive advantage and organizational performance. Omega, 34(2), 107-124. https://doi.org/10.1016/j.omega.2004.08.002

Mahdi, O. R., \& Almsafir, M. K. (2014). The Role of Strategic Leadership in Building Sustainable Competitive Advantage in the Academic Environment. Procedia Social and Behavioral Sciences, 129, 289-296. https://doi.org/10.1016/j.sbspro.2014.03.679

Martínez-Costa, Micaela; Jimenez-jimenez, D. (2009). The Effectiveness of TQM The Key Role of Organizational Learning in Small Businesses. International Small Business Journal. Retrieved from http://journals.sagepub.com/doi/pdf/10.1177/0266242608098348

Miller, D. (1987). The structural and environmental correlates of business strategy. Strategic Management Journal, 8(1), 55-76. https://doi.org/10.1002/smj.4250080106

Mulyana, \& Sutapa. (2014). Peningkatan Kapabilitas Inovasi, Keunggulan Bersaing dan Kinerja melalui Pendekatan Quadruple Helix: Studi pada Industri Kreatif Sektor Fashion. Jurnal Manajemen Teknologi, 13(3), 304-321. https://doi.org/10.12695/jmt.2014.13.3.5

Nasser H. Zaied, A., Soliman Hussein, G., \& M. Hassan, M. (2012). The Role of Knowledge Management in Enhancing Organizational Performance. International Journal of Information Engineering and Electronic Business, 4(5), 27-35. https://doi.org/10.5815/ijieeb.2012.05.04

Omotayo, F. O. (2015). Knowledge Management as an important tool in organisational management: A review of literature. Library Philosophy and Practice (eJournal)., 1238, 1-23. $\quad$ Retrieved from http://digitalcommons.unl.edu/libphilprac/1238

Petty, R., \& Guthrie, J. (2000). Intellectual capital literature review. Journal of Intellectual Capital, 1(2), 155-176. https://doi.org/10.1108/1469193001034873

Piening, E. P., \& Salge, T. O. (2015). Understanding the Antecedents, Contingencies, and Performance Implications of Process Innovation: A Dynamic Capabilities Perspective. Journal of Product Innovation Management, 32(1), 80-97. https://doi.org/10.1111/jpim.12225

Roper, A. (1989). BUDGET HOTELS - A CASE OF MISTAKEN IDENTITY ?, 25-31.

Rudež, H. N., \& Mihalič, T. (2007). Intellectual capital in the hotel industry: A case study from Slovenia. International Journal of Hospitality Management, 26(1), 188-199. https://doi.org/10.1016/j.ijhm.2005.11.002

Saunila, M. (2014). Innovation capability for SME success: perspectives of financial and operational performance. Journal of Advances in Management Research, 11(2), 
163-175. https://doi.org/10.1108/JAMR-11-2013-0063

Serenko, A., \& Bontis, N. (2013). Investigating the current state and impact of the intellectual capital academic discipline. Journal of Intellectual Capital, 14(4), 476-500. https://doi.org/10.1108/JIC-11-2012-0099

Setyawati, H. (2013). Pengaruh Orientasi Kewirausahaan Dan Orientasi Pasar Terhadap Kinerja Perusahaan Melalui Keunggulan Bersaing Dan Persepsi Ketidakpastian Lingkungan Sebagai Prediksi Variabel ModerasI, 20-31.

Snowden, S. P.-K. C. (2016). Redefining business success in a changing world. 19th Annual Global CEO Survey, (January), 42. Retrieved from http://www.pwc.com/gx/en/ceo-survey/2016/landing-page/pwc-19th-annualglobal-ceo-survey.pdf

Sulistyo, H., \& Siyamtinah. (2016). Innovation capability of SMEs through entrepreneurship, marketing capability, relational capital and empowerment. Asia Pacific Management Review, 21(4), 196

Surya Kusuma, Fifi; Devie, D. (2013). Ananalisa Pengaruh Knowledge Management Terhadap keunggulan Bersaing dan Kinerja Perusahaan. Business Accounting Review, 1 No. 2.

Tavitiyaman, P., Qu, H., \& Zhang, H. Q. (2011). The impact of industry force factors on resource competitive strategies and hotel performance. International Journal of Hospitality Management, 30(3), 648-657. https://doi.org/10.1016/j.jhm.2010.11.010

Todericiu, R., \& Stăniț, A. (2015). Intellectual Capital - The Key for Sustainable Competitive Advantage for the SME's Sector. Procedia Economics and Finance, 27(15), 676-681. https://doi.org/10.1016/S2212-5671(15)01048-5

Wu, J., \& Chen, X. (2012). Leaders' social ties, knowledge acquisition capability and firm competitive advantage. Asia Pacific Journal of Management, 29(2), 331350. https://doi.org/10.1007/s10490-011-9278-0

Zehir, C., Köle, M., \& Yıldız, H. (2015). The Mediating Role of Innovation Capability on Market Orientation and Export Performance: An Implementation on SMEs in Turkey. Procedia-Social and Behavioral Sciences, 207, 700-708. https://doi.org/10.1016/j.sbspro.2015.10 